Citation

White W.B., 2009, Proceeding 15th International Congress of Speleology, Volume II, UIS, Texas, pp 1112-1116

\title{
ENVIRONMENTAL PROBLEMS OF TELAGA (DOLINE POND) IN GUNUNSEWU KARST, JAVA INDONESIA
}

\author{
EKO HARYONO, TJAHYO NUGROHO ADJI, MARGARETA WIDYASTUTI \\ Karst Research Group, Geography Faculty, the University of Gadjah Mada, Yogyakarta Indonesia
}

\begin{abstract}
Telaga is a pond formed in the dolines as a result of ponor plugging. A total number of 443 telaga are randomly distributed within Gunung Sewu Karst $\left(3,200 \mathrm{~km}^{2}\right)$. Telaga used to provide approximately $90 \%$ of the local people's water supply (before 1990s). However, most telaga are currently drying up, only 30 telaga remain perennial. The environmental problems of the telaga can be grouped into three categories, namely a) diminishing storage, b) rapid water loss, and c) water quality deterioration. Diminishing storage has been resulted from rapid sedimentation (caused by extensive agriculture to the karst hills) and the increase of infiltration (caused by the lost of karst soil cover). Rapid water loss is due to basal leakage (caused by removal of bottom soil during telaga deepening practices or embankment construction) and higher evaporation (caused by higher wind velocity and warmer local temperature). Water quality deterioration has been resulted from multiple usages (human bathing, washing, animal bathing, animal drinking, fishery) inside the telaga, as a result waste is retained in the telaga water body. Major contaminants of telaga water are phosphate, COD, nitrate, detergent, collie bacteria, and suspended solid. Proposed rehabilitation options which may be easily applied among others are, a) leaving the upper slope of karst hills for perennial crops, b) imposing Guyang Warak tradition, c) sealing telaga bottom with asphalt soaked sacks buried in clay, c) replacing concrete levy with a sandwich of stone pile and clay, d) planting readily consumed perennial crops along telaga sides, and e) establishing simple bathrooms outside telaga so that waste will not remain in the telaga water body.
\end{abstract}

Keywords : Karst water resource, doline lake, telaga, Gunun Sewu Indonesia

\section{Introduction}

Water resource is a pivotal issue of Gunung Sewu karst. During dry season, this area undergoes severe water shortage. More than 41 per cent of the population of Gunung Sewu karst has no access to safe drinking water. In some localities, the population is forced to carry water from distant springs or telaga. Resurgences emerge in the southern coastline which is far from settlement. Underground river course, on the other hand, are found in great depth $(>100 \mathrm{~m})$ and not readily assessed by local people. High investment and operational cost make under ground water taping infrastructure is not affordable to local government and private sectors.

The most assessable water, though in small quantity, are springs and telaga. Karst springs however emerge only in few places and provide water demand for only few nearest villages. Instead, the most assessable water resource is telaga. Telaga are more abundant and dispersedly distributed. For that reason, telaga were used to be the main water resources, especially before 1990s, when water supply infrastructure had not been established yet. Unfortunately, the existing water supply infrastructures only provides $0.25 \%$ of entire water demand. Local people thereafter still use telaga for they daily live, especially for bathing, washing, and animal drinking. For drinking water, local people relay on rain water collected during rainy season and water tanker brought from distant areas. Telaga currently are facing several problems, most of telaga are drying up, and less than $10 \%$ remains perennial. This paper accordingly tries to discuss the environmental problem of telaga, the affecting factors, and possible rehabilitation measures. Analyzes and discussion are based on data form previous works, field observation, and measurement from topographical map and aerial photograph. 


\section{The settings of Gunung Sewu karst}

Gunung Sewu karst is well known for its typical morphology which is generally considered a type example of cone or kegelkarst (Lehmann, 1936). Gunungsewu karst stretches $85 \mathrm{~km}$ west-east covering three provinces of Yogyakarta, Central Java, and East Java. Its north-south width varies between 10 and $29 \mathrm{~km}$ with approximate area of $1300 \mathrm{~km}^{2}$. The Gunung Sewu karst is adjacent to the Indian Ocean on the south central coast of Java. Elevation range is between zero and $512 \mathrm{~m}$ above mean sea level, and the highest portions centrally located about $25 \mathrm{~km}$ from the cost line. The annual rainfall varies between $1500 \mathrm{~mm}$ and $2986 \mathrm{~mm}$ annually. Mean annual temperature is about $27^{\circ} \mathrm{C}$ (Haryono and Day, 2005).

The Gunung Sewu karst is made up of Neogen (Middle Miocene and Upper Pliocene) limestone of Wonosari-Punung Formation. The limestone is composed of massive coral limestone in the south and bedded chalky limestone in the north (Balazs 1968; van Bemmelen 1970; Waltham et al. 1983; Surono et al. 1992; Rahadjo et al., 1995). Total thickness of the limestone exceeds $650 \mathrm{~m}$. The underlying rocks of the area are volcanic clastic rocks, including tuff, andesitic breccias, and tufaceous sandstone. The areas have been subjected to uplift since the Late Pliocene forming plateau morphology. Gunung Sewu karst has also been tectonically active resulted in severe jointing and faulting.

\section{Telaga characteristics}

In addition to conical morphology, telaga is the second characteristic of Gunung Sewu karst. This phenomenon is rarely found in other karst areas of Indonesia. Telaga are formed in the base of cockpits as a result of ponor plugging. The sediment is consisted of silty clay material with depth up to more than 2 meters. No further researches are available explaining the occurrences and genetic of telaga. The only information easily observed from topographical map is that telaga are randomly distributed within entire area of Gunung Sewu Karst reaching a total number of 443 (Figure 1). Such random distribution is confirmed by nearest neighborhood index. Nearest neighbor index of telaga distribution in Gunung Sewu karst is 9.11. The area of telaga ranges approximately from 0.25 to 3.5 ha forming several plan forms. Telaga plan forms are controlled by bottom cockpit morphology.

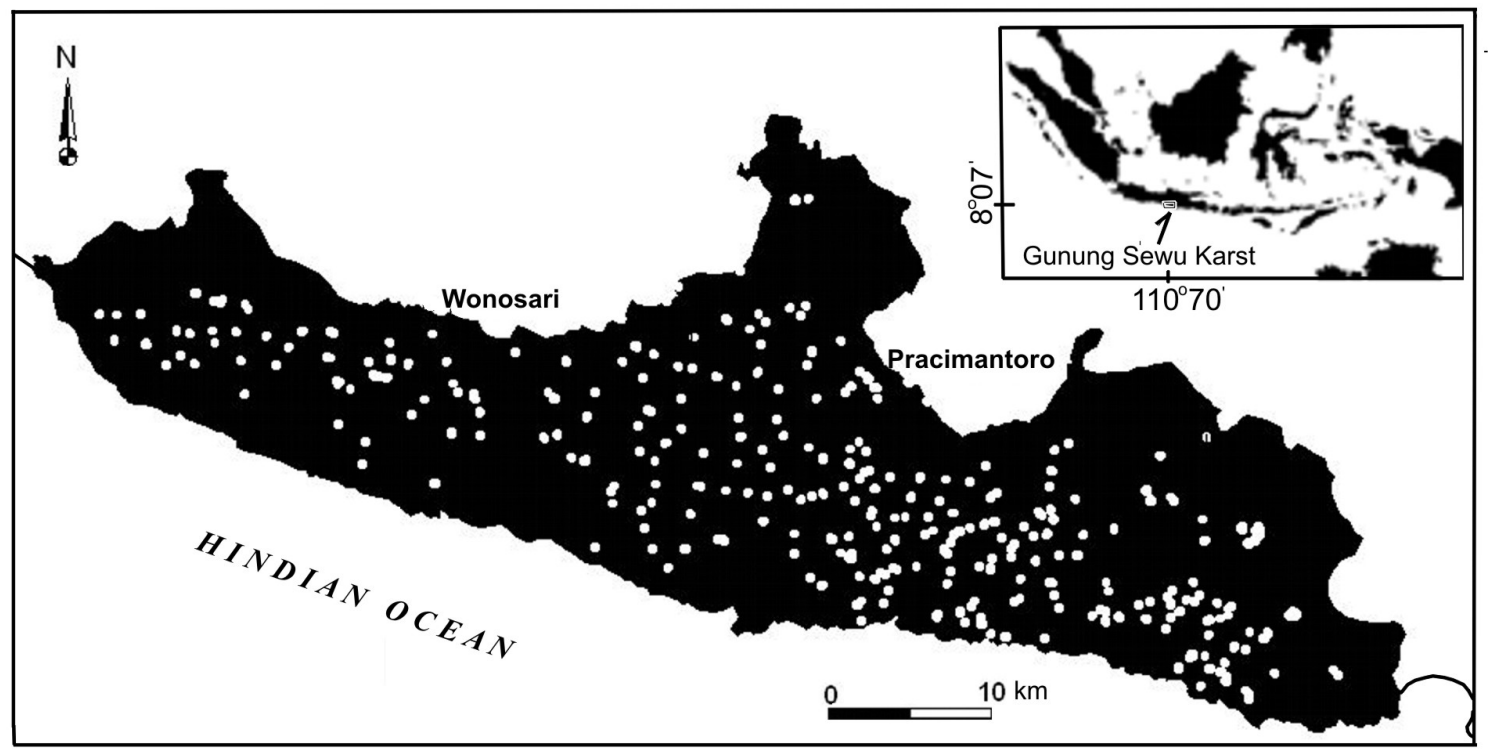

Figure 1. Distribution of telaga in Gunungsewu Karst (compiled from topographical maps)

Telaga are recharged by direct rain fall and surface runoff from surrounding areas within the cockpit. Works by Setyahadi (2002) and Macdonald and partners (1984) showed that coefficient runoff in the area generally varies between 3 up to $28 \%$. Runoff is drained to the telaga through galleys or manmade ditches. The recharge area is mostly characterized by limestone outcrop with limited soil cover. Soils are patchy distributed with very small coverage within terraces. As a result of limited soil cover, thereafter subcutaneous flow in the area is likely not a significant control in telaga hydrology, especially in recharging telaga. Telaga water is drained through ponor as a shaft flow and dry up through evaporation. 
Measurement from geometrically corrected aerial photograph founds that cockpits area varies between 0.018 and $2,105 \mathrm{~km}^{2}$ or $0.146 \mathrm{~km}^{2}$ in average $(\mathrm{N}: 386)$. Land covers of the area are combination between dry land cultivation and mix timber plantation. Settlements are located scatterly in the entirely karst area with average population density of 348 people $/ \mathrm{km}^{2}$. Bare lands are also found in some localities forming karren field in various forms. In some places, karren outcrops up to $1.5 \mathrm{~m}$ high indicating severe soil losses.

\section{Environmental problems}

Environmental problems of telaga are summarized in Table 1. The environmental problems of the telaga can be grouped into three categories, namely a) decreasing storage, b) rapid water loss, and c) water quality deterioration. Decreasing storage has been resulted from rapid sedimentation caused by erosion. Accelerated erosion has taken place since the early $19^{\text {th }}$ century due to deforestation and agricultural extensification. Higher population growth and limited land have forced people to cultivate upper slope of karst hills. Soil plowing during land preparation does loosens soil aggregate and increase soil erodibility. As a result, in the beginning of rainy season when plantation has not grown yet, severe soil erosion takes place. High erosion rate of Gunung Sewu rate can be also indicated by the occurrences of karren protruding up to one meter high (Haryono, et.al., 2002). Further consequence of soil erosion related to telaga storage is the decrease of surface runoff recharging telaga. Less soil cover has brought about opening of secondary porosity. This in turn will inevitable account for the higher infiltration rate and less surface runoff.

Table 1. Environmental problems of Telaga (doline pond) in Gunungsewu Karst

\begin{tabular}{|c|c|c|}
\hline Environmental Problems & & Affecting Factors \\
\hline \multirow[t]{3}{*}{$\begin{array}{l}\text { I. Decreasing } \\
\text { volume/storage } \\
\text { capacity }\end{array}$} & 1.1. Sedimentation & $\begin{array}{l}\text { 1.1.1. deforestation and agricultural } \\
\text { extensification in the doline recharge } \\
\text { areas }\end{array}$ \\
\hline & & $\begin{array}{l}\text { 1.1.2. Loosening soil aggregate due to soil } \\
\text { preparation practice in the end of dry } \\
\text { season }\end{array}$ \\
\hline & $\begin{array}{l}\text { 1.2. Decreasing recharge } \\
\text { due to less surface } \\
\text { runoff }\end{array}$ & 1.2.1. Thinning soil cover \\
\hline \multirow[t]{2}{*}{ II. Increasing water losses } & 2.1. Basal leakage & 2.1.1. Sediment excavation in doline bottom \\
\hline & $\begin{array}{l}\text { 2.2. Increasing } \\
\text { evaporation }\end{array}$ & $\begin{array}{l}\text { 2.2.1. Increasing temperature due to less forest } \\
\text { cover } \\
\text { 2.2.2. Increasing wind velocity due to less } \\
\text { forest cover around doline pond }\end{array}$ \\
\hline $\begin{array}{l}\text { III. Decreasing water } \\
\text { quality }\end{array}$ & $\begin{array}{l}\text { 3.1. Waste from inside } \\
\text { utilization (bathing } \\
\text { and washing) } \\
\text { 3.2. Waste from recharge } \\
\text { area }\end{array}$ & $\begin{array}{l}\text { 3.2.2. Organic and inorganic waste brought by } \\
\text { surface runoff }\end{array}$ \\
\hline
\end{tabular}

Rapid water losses are caused by basal leakage and evaporation. Basal leakage is resulted from removal of bottom sediment during telaga rehabilitation practices. Since the 1990s, public work office has deepened and constructed embankment encircling telaga. Sediment has been removed in bid of increasing telaga storage. This practice unseals ponors and inevitably increases water losses. It has been echoed by Setyahadi (2002) and Putra (2003) that natural telaga have longer inundation period than rehabilitated telaga. From five telaga measurement conducted by Setyahadi (2002) and 14 telaga by MacDonald and Partners (1984), water losses of telaga through infiltration ranges between $0-26.3 \mathrm{~mm} /$ day. Ponor opening 
is likely also caused by accelerated dissolution in the underlying rock of telaga. Higher dissolutions rate is resulted from accumulated soil $\mathrm{CO}_{2}$ brought by erosion from upper slope areas.

Accelerated water losses in karst Gunungsewu is also resulted from higher evaporation. Changing of micro climate due to less vegetation cover around telaga is the factor accounted for higher evaporation. Less vegetated area in this case increases local temperature and wind velocity. Land in the surrounding telaga is cultivated for dry land field. Average temperature is $27^{\circ} \mathrm{C}$ and the highest temperature during mid day is up to $34^{\circ} \mathrm{C}$. Average evaporation of the area measured from pan evaporation is 5.4.mm/dy (Putra, 2003). This finding is higher than Setyahadi (2002) measurement in area with denser vegetated cover which resulted $4.4 \mathrm{~mm} /$ day.

Water quality deterioration has been resulted from multiple usages inside telaga including human bathing, washing, animal bathing, animal drinking, and fishery, thus waste is left and retained in telaga. The only measure imposed by local people is separating telaga into two compartment for human and animal by constructing dike. This practice only able to separate waste from animal and human, not to keep telaga from waste produced by bathing and washing activities. Contaminants are also brought by surface runoff either from surrounding areas, especially from agricultural land and settlement. Major contaminants of telaga water are phosphate, COD, nitrate, detergent, collie bacteria, and suspended solid. Phosphate and nitrogen are resulted from fertilizer. Bacteria collie is either from animal feces inside telaga or brought from the cathment area by surface runoff. Cattle are the second income generation of the Gunung Sewu people. Each family in the area has in average two cows or lamb, 20 chickens.

\section{Proposed Measures for Telaga Rehabilitation}

Telaga rehabilitation must be treated comprehensively for the sake of environmental management of Gunung Sewu karst entirely. Any measures can not be attributed solely for the telaga rehabilitation. In the case of Gunung Sewu karst, greater attention must be devoted to rehabilitize vegetation coverage through replanting perennial crops (reforestation). Since Gunung Sewu people are much relays on land resources, attempts should be made to ascertain that the perennial crops not only for the shake of conservation but also for income generation. Otherwise the program will fail. Agriculture is still the main activities to make living in Guung Sewu. In that regards, reforestation must not cover entirely plot of land but there must be mix or combination between seasonal crops and perennial crops. Seasonal crops is cultivated to fulfill staple food daily need, on the other hand perennial crops are both for conservation and consumption. In that regards perennial crops are planted in the upper slope of karst hills and seasonal crops are placed in the lower slope (Figure 2.). In attempt to keep the upper slope vegetated, perennial crops in the upper slope must be mixture between timber crop and non timber crops. If timber crops are cut down there still vegetation left. Re-vegetation measure in upper slope is intended to reduce erosion so that suspended material in telaga water and sedimentation can be reduced. Reforestation is also intended to improve micro climate especially in reducing temperature, wind velocity, and furthermore reducing evaporation. Planting perennial crops such fruit crops in telaga riparian area is also advisable, especially when the area is not cultivated for seasonal crops.

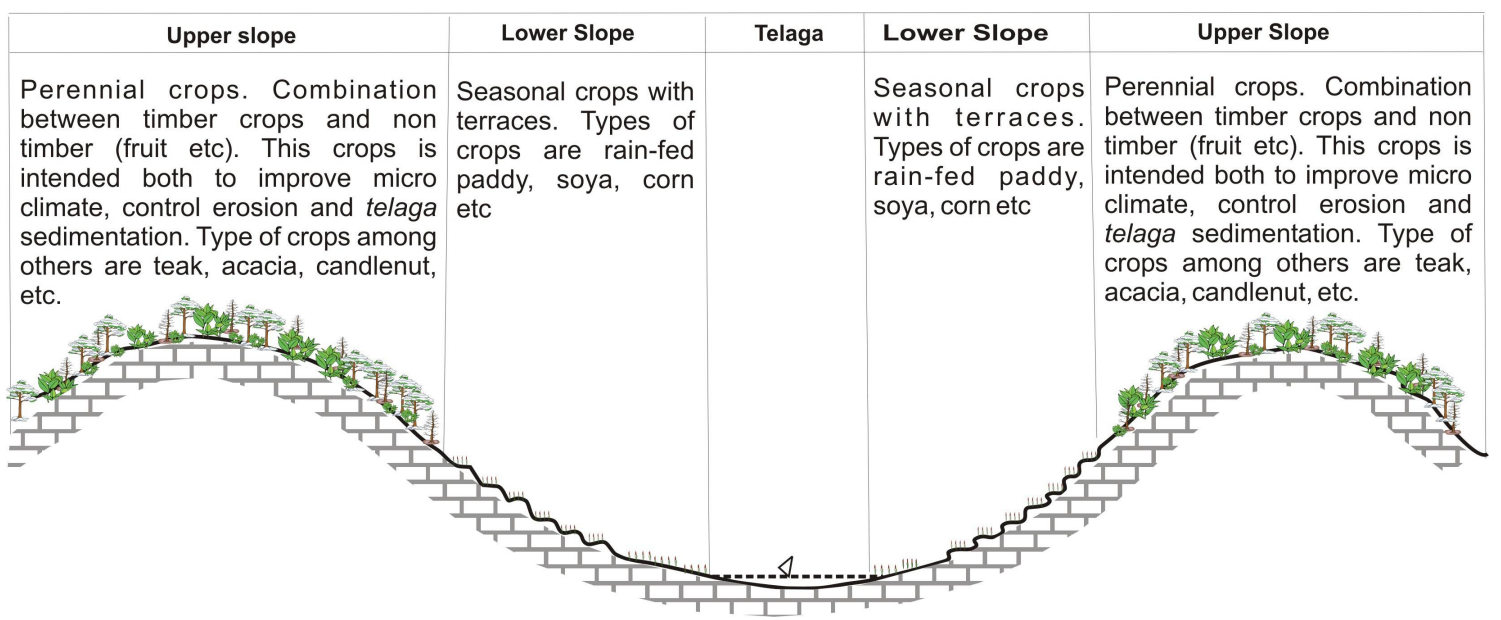


Figure 2. Recommended cropping pattern for telaga rehabilitation

The second measure is sealing the telaga bottom. Several practical techniques can be applied for this purpose. In some places of Gunung Sewu Karst, there is local wisdom dealing with telaga. The tradition is well known as Guyang Warak (bull bathing). Guyang Warak is a traditional ceremony conducted thorough bringing as many as cows to the telaga in an attempt to stir up sediment in the base of telaga. Such old tradition was believed to have sealing mechanism. Empirically, this practice does improve sealing capability of sediment. It has been understood that high content of $\mathrm{Ca}$ in soil makes clay to be aggregated forming a porous structure that lets water seeps through easily. Bu stirring up the sediment, clay will be dispersed. This tradition has already been forgotten and never been applied anymore. Revitalizing such local wisdom surely will help not only for telaga rehabilitation, but also important for cultural preservation. If this practice is organized well, the event can be developed as a tourist attraction.

Rehabilitation of telaga concerning with leakage problem can be solved also through engineering treatment. However the better one is those affordable and applicable. Depending much upon imported material will no be effective. The easiest way to seal leakage is putting asphalt soaked sacks in the base of telaga. Asphalt and sacks are local material that is sold in local market. This treatment is carried out by excavating sediment telaga one up to two meter deep, putting asphalt-soaked sack to telaga bottom, and overlying sacks with clayed soil or with previously removed sediment at $0.5 \mathrm{~m}$ thick. Another engineering rehabilitation of telaga is replacing concrete embankment with a sandwich of stone pile and clay. Many masonry telaga embankments are cracked and even broken leading to water leakage. Cracking of concrete embankment is resulted from shrinking and swelling properties of clayed soils in the area. In such condition, stone piling and with clay inside is more favorable and will not be affected by swelling and shrinking of soils. Asides of those technical advantages, embankment with stone pile and clay are simpler, easier, and cheaper construction.

The last rehabilitation measure of telaga is controlling waste entering telaga water. As mention early, water quality deterioration is resulted from washing and bathing inside telaga. To coup with this problem, washing and bathing must be placed outside telaga. Bathroom must be provided outside telaga but still near telaga area. The bathroom must be provided with well. The well actually is not real well, but it is just small part of telaga which is separated by embankment functioned as water filter. On the contrary waste from bathroom is also provided with sanitary system in such a way that waste water from bathroom can be filtered before re-entering telaga.

\section{References}

Balazs D. (1968) Karst Regions in Indonesia, Karszt es Barlangkutatas, Volume 5, Budapest, 61 p. Bemmelen, R.W. Van. (1970) The Geology of Indonesia, Vol IA. Second edition, Martinus Nijhoff, The Hgue, $752 \mathrm{p}$.

Haryono, E., Y. Lestari, D. Kusuma (2002) Sedimentasi Danau Dolin di Karst Gunungsewu, Prosiding Simposium Nasional on Sediment-Related Disaster Management. SABO Centre-Japan Internatioanal Coporation Agency JICA, Yogyakarta, p. 655-661.

Haryono E., M. Day (2004) Landform Differentiation within The Gunung Kidul Kegelkarst, JavaIndonesia. Journal of Cave and Karst Studies 66 (2), 62-68.

Lehmann H. (1936) Morphologiche Studien auf Java. Gogr, Abh, 3, Stutgart, p. 144.

MacDonald and Patners (1984) Greater Yogyakart Groundwater Resources Study. Volume 3C. Directoral General of Water Resources Development, Jakarta, p. 157.

Putra, Y.A. (2003) Study koofisien limpasan permukaan karst Gunung Sewu. Thesis, unpublished. Geography Faculty-UGM, Yogyakarta, p. 119.

Rahadjo, W., S. Rumidi, H.M.D. Rosidi (1995) Peta Geologi Lembar Yogyakarta, Jawa. Second Ed. Pusat Penelitian dan Pengembangan Geologi, Bandung, p. 22.

Setyahadi, A. (2002) Koofisien limpasan permukaan kawasan karst Gunung Sewu. Thesis, unpublished. Geogragphy Faculty-UGM, Yogyakarta, p. 156.

Santosa, L.W. (2007) Kerusakan telaga dolin di wiliyah perbukitan karst Kabupaten Gunungkidul Jurnal Kebencanaan Indonesia 1(3), 176-193.

Surono, B. Toha, J. Sudarno (1992) Peta Geologi Lembar Surakarta-Giritontro, Jawa. Pusat Penelitian dan Pengembangan Geologi, Bandung, p. 17. 
